H.K. Lappalainen ${ }^{1,2}$, T. Petäjä ${ }^{1}$, V-M. Kerminen ${ }^{1}$, R. Makkonen ${ }^{1}$, A. Malkamäki ${ }^{1}$, P. Alekseychik ${ }^{1}$, N. Zaitseva ${ }^{3}$, J. Kujansuu ${ }^{1}$, T. Ruuskanen ${ }^{1}$, A. Lauri ${ }^{1}$, E. Kyrö ${ }^{1}$, S. Mazon ${ }^{1}$, A. Scherbinin ${ }^{4}$, P. Konstantinov ${ }^{5}$, M. Kaukolehto ${ }^{1}$, N. Chubarova ${ }^{5}$, T. Laurila ${ }^{2}$, E. Asmi ${ }^{2}$, S. Juhola ${ }^{4}$, J. Bäck ${ }^{6}$, T. Vesala ${ }^{1}$, P. Hari ${ }^{6}$, M. Arshinov ${ }^{7}$, A. Mahura ${ }^{8}$, S. Arnold ${ }^{9}$, D. Spracklen ${ }^{9}$, A. Ding ${ }^{10}$, C. Fu ${ }^{10}$, H-C. Hansson ${ }^{11}$, V. Melnikov ${ }^{12,13}$, G. Matvienko ${ }^{7}$, A. Baklanov ${ }^{14}$, Y. Viisanen ${ }^{2}$, N. Kasimov ${ }^{5}$, H. Guo ${ }^{15}$, V. Bondur ${ }^{16}$, S. Zilitinkevich ${ }^{1,2,17}$, M. Kulmala ${ }^{1}$

\title{
PAN-EURASIAN EXPERIMENT (PEEX) PROGRAM - TOWARDS ARCTIC-BOREAL SYSTEM UNDERSTANDING
}

Pan-Eurasian Experiment (PEEX) program (https://www.atm.helsinki.fi/peex/) is an international, multidisciplinary, multiscale and multidimensional bottom up initiative established in 2012. The initiative has grown fast and currently it involves research communities from 25 different countries with a network of approximately 2000 researchers from Europe, Russia and China. The focus of the PEEX initiative is to solve interlinked global environmental challenges influencing societies in the Northern Eurasian region, specifically in the Arctic-boreal regions and the Arctic Ocean, which are located at latitudes higher than $45^{\circ} \mathrm{N}$. These areas are expected to undergo substantial changes during the next decades (IPCC, 2014). The importance of the Northern regions even in a global point of view is foreseen to increase not only because of the climate change, but also due to globalization, shipping, demography and utilization of natural resources. The Arctic-boreal Northern Eurasian region, and especially the arctic coastal lines and Siberian region of the Russian territory, are extremely crucial for and sensitive to the global climate. Permafrost thawing together with the Arctic sea ice changes will have multiple environmental (greenhouse gas emissions, air quality), economic (energy production, use of mineral, traffic and shipping and infrastructures) and societal (urbanization, cultural changes) consequences, which are intricately interconnected with each other.

In the PEEX approach the climate change is key driver in the dynamics of the land, atmosphere, aquatic and societal systems. The system-based structure of PEEX introduces altogether twelve thematic research areas. The approach will piece-by-piece develop into a holistic system understanding, which the PEEX community and stakeholders can quantify the most dominant feedbacks and interactions between the components within the system providing novel understanding in the dynamics of Arctic-boreal biogeochemical cycles of e.g. water, carbon, nitrogen

\footnotetext{
${ }^{1}$ Dept. of Physics, University of Helsinki, Finland; e-mail: hanna.k.lappalainen@helsinki.fi.

${ }^{2}$ Finnish Meteorological Institute, Helsinki, Finland.

${ }^{3}$ Dept. of Earth Sciences, Russian Academy of Sciences, Russia.

${ }^{4}$ Dept. of Environmental Sciences, University of Helsinki, Finland.

${ }^{5}$ Moscow State University, Russia.

${ }^{6}$ Dept. of Forest Ecology, University of Helsinki, Finland.

${ }^{7}$ Institute of Atmospheric Optics, Tomsk 634055, Russia.

${ }^{8}$ Danish Meteorological Institute, Research and Development Department, 2100, Copenhagen.

${ }^{9}$ Institute for Climate and Atmospheric Science, School of Earth and Environment, University of Leeds, Leeds, LS2 9JT, UK.

${ }^{10}$ Institute for Climate and Global Change Research \& School of Atmospheric Sciences, Nanjing University, 210023 Nanjing, China'.

${ }_{11}^{11}$ Dept. of Environmental Science and Analytical Chemistry, Stockholm University, Sweden.

${ }^{12}$ Tyumen State University, Russia.

${ }^{13}$ Tyumen Scientific Center, Siberian Branch, Russian Academy of Science, Russia.

${ }^{14}$ World Meteorological Organization, 1211 Genève, Switzerland.

${ }^{15}$ Institute of Remote Sensing and Digital Earth, Chinese Academy of Sciences, Beijing 100101, China.

${ }^{16}$ AEROCOSMOS Research Institute for Aerospace Monitoring, Moscow, Russia.

${ }^{17}$ Dept. of Radiophysics, Nizhny Novgorod State University, Russia.
} 
and sulfur. "The geographical domain of PEEX covers natural and urban environments of the Northern Eurasian region. China is included due to its crucial importance on its climate - air quality interactions. Siberia and Arctic Ocean are at the core geographical region within the PEEX domain. The majority of the PEEX domain is within Russia and China.

\section{А.М. Новикова ${ }^{1}$, А.Б. Полонский ${ }^{2}$, А.А. Новиков ${ }^{3}$ \\ СРАВНЕНИЕ ВОЗМОЖНОСТЕЙ ИНТЕРПОЛЯЦИОННЫХ МОДУЛЕЙ QGIS ДЛЯ МОРСКИХ КЛИМАТИЧЕСКИХ ИССЛЕДОВАНИЙ ПРИ РАБОТЕ С МАССИВОМ ДАННЫХ МАЛОЙ ОБЕСПЕЧЕННОСТИ}

Резюме. В статье с позиции геоинформационного и геостатистического подходов показана актуальность активного применения современных методов пространственного анализа океанологических данных. Проанализированы возможности некоторых статистических модулей открытой ГИС (QGIS) для решения практических задач оперативной оченки качества данныхх. Проведена оченка интерполяиионных модулей QGIS, использующих методы кригинга и радиальных базисных функиий, при работе с массивом данных малой обеспеченности.

Ключевые слова: QGIS, статистические модули, кригинг, регуляризованный сплайн с натяжением, бикубическая сплайн-интерполяция с регуляризацией Тихонова.

Введение. Несмотря на значительный объём океанологических данных, получаемых дистанционными методами зондирования, а также другими современными способами исследования акваторий, существует проблема неравномерности распределения данных для изучения океанологических процессов даже климатического масштаба, которую обычно решают при помощи различных методов интерполяции. В океанологии наиболее широко используется метод оптимальной интерполяции, разновидности которого реализованы в различных геоинформационных системах (ГИС). ГИС могут предложить практичную рабочую среду для интеграции, анализа и визуализации климатических и океанографических данных, несмотря на то, что в этой области ГИС пока еще мало используются (подробнее в [Новикова, 2015]). В настоящей работе приводится опыт использования открытой ГИС QGIS для океанографических приложений на примере построения климатических карт температуры поверхностного слоя Чёрного моря с использованием массива данных малой обеспеченности.

Для достижения поставленной цели в QGIS можно задействовать несколько модулей. Некоторые из них являются приложениями самой QGIS, например, «Модуль интерполяции» и «Геоалгоритмы QGIS», но большая часть задействует ресурсы сторонних ГИС, таких как SAGA и GRASS, а также осуществляет доступ к библиотекам GDAL/OGR через панель «Инструменты анализа». Так как встроенные модули QGIS и геоалгоритмы GDAL/OGR изначально создавались для получения цифровых моделей рельефа, их использование для интерполяции данных наблюдений, характеризующихся интенсивной пространственно-временной изменчивостью, проблематично. Гораздо более широкое применение находят модули GRASS-геоалгоритмы и SAGA-геоалгоритмы, где в качестве интерполяторов представлены различные варианты сплайнов (радиальных базисных функций) и кригинга.

\footnotetext{
${ }^{1}$ ФГБНУ «Институт природно-технических систем», отдел актуальных проблем океанографии, Севастополь, 299011, Россия, старш. инж.-исслед.; e-mail: anelkapi@bk.ru.

2 ФГБНУ «Институт природно-технических систем», Океанографический центр, Севастополь, 299011, Россия, руководитель, профессор, докт. геогр. н.; e-mail: apolonsky5@mail.ru.

${ }^{3}$ Филиал Московского государственного университета им. М.В. Ломоносова в г. Севастополе, отделение географии, Севастополь, 299001, Россия, старш. преподаватель; e-mail: a_novik@bk.ru.
} 